further. Since there were apparently normal male siblings in the families of pairs 1 and 4, and in others reponted in the literature, the condition must be inherited either as an autosomal recessive or as a sex-linked recessive character. Elucidation of the exact mode of inheritance requires a search for the abnormality in succeeding generations. Though patients with this condition have been reported to be fertile (Nilson, 1939; Young, 1951) proof of paternity in these cases has been lacking. The one report of a spermogram (Giacobine, 1946) showed a reduced total count with few motile sperms and $35 \%$ atypical forms: both patients in pair 1 had azoospermia. Since one report in the literature concerns the improbable case of a man with bilateral cryptorchidism having eight children (Keiffer, 1909) the evidence for fertility as a whole seems somewhat questionable.

In view of the high incidence of cryptorchidism in this condition, and the finding in patients $B, E$, and $F$ that the descended testis was also hypoplastic, a lack of fertility would not be surprising, but more fundamental questions about cryptorchid testis are raised by this. It is not known why the normal testis descends nor whether cryptorchid testes are primarily or secondarily hypoplastic (Salle et al., 1968); the present cases favour the former, since the descended testes were abnormal. A possible explanation for the syndrome could be that though androgens are produced normally by the interstitial cells Müllerian-inhibiting substance is not produced by the hypoplastic seminiferous tubules. If this were correct, however, persistent Müllerian structures would occur more frequently in cryptorchid subjects whose testes are not histologically different from those of the present patients. An inherited error in the production of or response to Müllerianinhibiting substance is therefore more likely.

It is well known that malformed structures have a greater than normal incidence of malignancy, which explains the increased incidence of neoplasia in cryptorchid testes whether or not they are surgically placed in the scrotum (Robinson and Engle, 1954). Presumably this is the reason for the seemingly high incidence of malignancy in men with persistent Müllerian structures reported in the literature-seminoma (Boulvin, 1964, and patient A), choriocarcinoma (Taub, 1954), embryonal carcinoma (Metcalfe, 1930), and teratoma (Dvorak, 1924; d'Arcy McCrea, 1930). There is, however, no good evidence that the cryptorchid testes of these patients are more susceptible to malignant change than the testes of "normal" oryptorchid subjects, and we do not agree with Jirasek (1971) that there is more indication than is usual in cryptorchid subjects to remove the testes of these individuals.

We are grateful to Professor Hedinger (Zürich) for his advice on testicular histology and to Dr. Nathalie Josso (Paris) for her helpful criticism of the manuscript. C.G.D.B. gratefully acknowledges the financial support of the Wellcome Trust.

\section{References}

Boulvin, R. (1964). Annales de Chirurgie, 18, 1340.

d'Arcy McCrea, E. (1930). British fournal of Surgery, 18, 91

David, L., Saez, J. M., and Francois, R. (1972). Acta Paediatrica Scandinavica, 61, 249 .

Dvorak, R. (1924). Virchows Archiv für pathologische Anatomie und Physiologie, 251, 616.

Elger, W. (1966). Archives d'Anatomie Microscopique et de Morphologie

French, F. S., et al. (1966). Fournal of Clinical Endocrinology and Metabolism, 26, 493 .

Giacobine, J. W. (1946). American fournal of Surgery, 72, 604.

Güell-González, J. R., Paramio-Ruibal, A., and Delgado-Morales, B. (1970) Revue Roumaine d'Endocrinologie, 7, 343 .

Jirasek, J. E. (1971). In Development of the Genital System and Male Pseudohermaphroditism, ed. M. M. Cohen, p. 88. The Johns Hopkins Press, Baltimore.

Josso, N. (1972a). Biology of the Neonate, 20, 368

Josso, N. (1972b). Fournal of Clinical Endocrinology and Metabolism, 34, 265. Josso, N. (1973). Acta Paediatrica Scandinavica, 62, 89.

Jost, A. (1947). Archives d'Anatomie Microscopique et de Morphologie Expérimentale, 36, 271.

Jost, A. (1972). In Mammalian Reproduction, ed. H. Gibian and E. J. Plotzt, p. 4. Heidelberg, Springer.

Keiffer (1909). Gynécologie, 13, 138.

Metcalfe, R. H. (1930). British Yournal of Surgery, 18, 335.

Nilson, O. (1939). Acta Chirurgica Scandinavica, 83, 231.

Petersson, F. (1964). Lancet, 1, 675.

Robinson, J. N., and Engle, E. T. (1954). Fournal of Urology, 71, 726.

Royer, P., Pellerin, D., Habib, R., Vermeil, G., and Rodriguez-Soriano, J. (196i). Annales de Pédiatrie, 37, 143.

Salle, B., Hedinger, C., and Nicole, R. (1968). Acta Endocrinologica, 58, 67. Taule, B., Hedinger, C., and Nicole, R. (1968).

Young, D. (1951). Fournal of Obstetrics and Gynaecology of the British Empire, 58, 830 .

\title{
Insulinopenic Diabetes in Africa
}

\author{
A. C. B. WICKS, J. J. JONES
}

British Medical fournal, 1973, 1, 773-776

\section{Summary}

The high proportion of unrefined carbohydrates (maize meal) in the diet of Africans could be responsible for their low insulin secretion. The consequent insulinopenia in the general African population may explain the comparative rarity of typical non-insulin dependent diabetes mellitus, and also the virtual absence of coronary heart disease. Changes in growth hormone secretion and in serum lipids, known to be associated with diabetes in Europeans, are also found in African patients. \footnotetext{
The Godfrey Huggins School of Medicine, University of Rhodesia,
Salisbury

A. C. B. WICKS, M.B., M.R.C.P., Lecturer in Medicine

J. J. JONES, PH.D., M.R.c.s., Professor of Preclinical Studies
}

\section{Introduction}

Diabetes mellitus was thought to be a rare disease in the indigenous populations of Africa (Tulloch, 1966), and coronary thrombosis as a complication is virtually unknown (Jackson et al., 1966; Seftel and Walker, 1966). In this paper an attempt is made to determine how far the characteristic features of diabetes in Africans can be related to diet and to insulin and growth hormone secretion.

\section{Patients and Methods}

In 1971, 107 newly diagnosed diabetic patients were admitted to Harare Hospital for stabilization. Of these, 20 were already receiving insulin and, of the remaining 87, 76 were selected at random for serum insulin assay before starting treatment. After an overnight fast, venous blood was collected for insulin assay (Hales and Randle, 1963) from 42 of these patients during a 50-g oral glucose tolerance test.

The results for insulin secretion during the glucose tolerance test from the healthy contrast group of 50 urban male 
African cleaners of the same social and economic group have already been reported (Wapnick et al., 1972). A combined oral glucose-intravenous tolbutamide test was given to 48 of the diabetic patients including 14 from the oral glucose tolerance group, and also to 29 non-diabetic volunteers. After an overnight fast, a venous blood sample was collected, $50 \mathrm{~g}$ glucose was taken by mouth, 45 minutes later $1 \mathrm{~g}$ tolbutamide was injected intravenously, and five minutes later a further sample of venous blood was collected. After an overnight fast, six of the healthy contrast group and 12 of the diabetic patients, selected at random, had venous blood samples collected for growth hormone assay (Schalch and Parker, 1964) before and immediately after 20 minutes' exercise ( 400 by 30 cm stepping test). Venous blood samples collected from 30 diabetic patients and 12 members of the contrast group during the oral glucose tolerance test were also assayed for growth hormone.

Venous blood samples were analysed for glucose using the autoanalyser ferricyanide method, and serum lipids (Watson, 1960; Duncombe, 1964; Eggstein, 1966) were measured in fasting venous blood from 97 of the newly diagnosed diabetic patients and from $\mathbf{4 0}$ members of the healthy contrast group. Serum iron (Bothwell and Mallet, 1955) and iron binding capacity (Bothwell et al., 1959) were measured in fasting blood serum from 94 of the patients. The excretion of faecal fat over a five-day period was measured in 98 of the patients when receiving a diet containing 70-80 g of fat a day. Wilcoxon's method was used for testing the significance of the difference between groups, and Pearson's product moment method was used for calculating correlation coefficients.

\section{Results}

The diabetic patients were compared with the healthy contrast group and classified according to their insulin secretion during the oral glucose tolerance test (see chart).

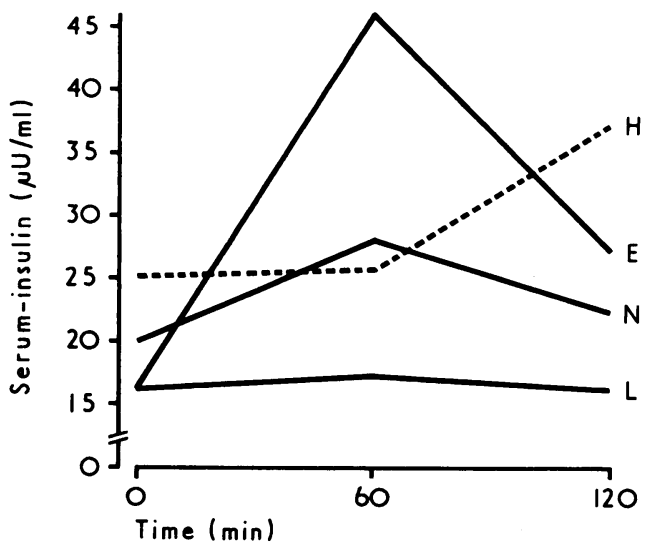

Change in serum insulin concentration during oral glucose tolerance test in three groups of diabetic patients $(H=H i g h / d e l a y e d . ~ N=$ Normal. $L=L o w$ secretion) and in the group of healthy European students (E) (Wapnick et al., 1972).

High Secretion.-A change in insulin concentration at 60 minutes greater than $+42 \mu \mathrm{U} / \mathrm{ml}$ (90th percentile of contrast group).

Delayed Secretion.-A change in insulin concentration greater at 120 minutes than at 60 minues and also greater than $+4 \mu \mathrm{U} / \mathrm{ml}$ (50th percentile of the contrast group).

Normal Secretion.-A change in insulin concentration greater at 60 minutes than at 120 minutes and between +5 and $+42 \mu \mathrm{U} / \mathrm{ml}$ (20th and 90th percentiles of the contrast group).

Low Secretion.-A change in insulin concentration of less than $+5 \mu \mathrm{U} / \mathrm{ml}$ at 60 minutes (20th percentile of contrast group) and less than $+2 \mu \mathrm{U} / \mathrm{ml}$ at 120 minutes (20th percentile of contrast group).

The fasting serum insulin, serum lipids and blood glucose concentrations, and the changes that occurred during the oral glucose tolerance test and after intravenous tolbutamide in

TABLE I-Results of Haematological Investigations in the Diabetic Patients and in the Healthy Contrast Group. Median Followed by 10th and 90th Percentiles

\begin{tabular}{|c|c|c|c|c|c|}
\hline & \multirow{2}{*}{ Healthy Contrast } & \multirow{2}{*}{ Total Diabetics } & \multicolumn{3}{|c|}{ Insulin Secreting Group } \\
\hline & & & High or Delayed & Normal & Low \\
\hline 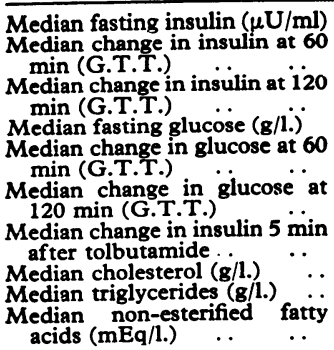 & $\begin{aligned} & 15(5 \text { to } 26) \\
&+ 15(+1 \text { to }+42) \\
&+ 4(+1 \text { to }+19) \\
& 0.68(0.53 \text { to } 0.82) \\
&+ 0.09(-0.08 \text { to }+0.45) \\
&+ 0.01(-0.16 \text { to }+0.28) \\
&+ 170(+46 \text { to }+500) \\
& 1.50(0.90 \text { to } 1.80) \\
& 0.80(0.35 \text { to } 2.30) \\
& 0.66(0.32 \text { to } 1.10)\end{aligned}$ & $\begin{aligned} & 21(a)(10 \text { to } 36) \\
+ & 2(0 \text { to }+20) \\
+ & 2(0 \text { to }+12) \\
& 2.30(0.90 \text { to } 4.20) \\
+ & 1.55(+0.80 \text { to }+2.40) \\
+ & 1.85(+0.90 \text { to }+2.25) \\
+ & 7(0 \text { to }+60) \\
& 2.45(e)(1.70 \text { to } 3.70) \\
& 1.90(f)(0.50 \text { to } 3.30) \\
& 0.60(0.40 \text { to } 1.30)\end{aligned}$ & $\begin{aligned} & 25(14 \text { to } 48) \\
&+ 0.5(0 \text { to }+76) \\
&+ 12(+7 \text { to }+56) \\
& 1.30(0.64 \text { to } 4.20) \\
&+ 1.20(+0.75 \text { to }+1.70) \\
&+ 1.80(+0.14 \text { to }+2.55) \\
&+ 8(d)(+4 \text { to }+20) \\
& 2.80(2.00 \text { to } 4.60) \\
& 2.30(0.65 \text { to } 3.15) \\
& 0.50(0.20 \text { to } 1.90)\end{aligned}$ & $\begin{array}{l}20(7 \text { to } 45) \\
+8(+3 \text { to }+45) \\
+3(-7 \text { to }+12) \\
2.60(0.97 \text { to } 5.50) \\
+1.55(+0.75 \text { to }+2.30) \\
+1.60(+0.50 \text { to }+2.25) \\
+7(d)(+4 \text { to }+8) \\
2.25(1.50 \text { to } 4.20) \\
1.15(0.75 \text { to } 4.00) \\
0.60(0.30 \text { to } 2.50)\end{array}$ & $\begin{array}{l}16(b)(8 \text { to } 32) \\
+1(-4 \text { to }+12) \\
0(-3 \text { to }+2) \\
2.80(0.95 \text { to } 3.50) \\
+1.60(c)(+0.80 \text { to }+2.50 \\
+2.00(+1.45 \text { to }+2.50) \\
+2(d)(0 \text { to }+5) \\
2.15(1.70 \text { to } 3.50) \\
2.25(0.40 \text { to } 3.20) \\
0.50(0.20 \text { to } 1.50)\end{array}$ \\
\hline tage in eac & group .. & 100 & 22 & 33 & 45 \\
\hline
\end{tabular}

$(a)=\mathrm{P}<0.002$ against Healthy. $(b)=\mathrm{P}<0.05$ against High. $(c)=\mathrm{P}<0.05$ against High. $(d)=$ Range $\mathrm{P}<0.05$ High against Low. (e) $=\mathrm{P}<0.001$ against Healthy. $(a)=\mathbf{P}<0.002$ against Heailthy.
$(f)=\mathbf{P}<0.05$ against Healthy.

TABLE II-Clinical and Laboratory Observations in the Groups of Diabetic Patients. Median Followed by 10th and 90th Percentiles

\begin{tabular}{|c|c|c|c|c|c|c|c|c|}
\hline & & & & & \multirow{2}{*}{ Total Diabetics } & \multicolumn{3}{|c|}{ Insulin Secreting Groups } \\
\hline & & & & & & High or Delayed & Normal & Low \\
\hline $\begin{array}{l}\text { Median age in years } \quad . \\
\text { Percentage of Females } \\
\text { Median weight as \% of desirable } \\
\text { Median systolic pressure }(\mathrm{mm} / \mathbf{H g}) \\
\text { Median diastolic pressure }(\mathrm{mm} / \mathbf{H g}) \\
\text { Percentage of ketonuria } \\
\text { Median faecal fat }(\mathbf{g} / 24 \mathrm{hr}) \quad \ldots \\
\text { Median iron }(\mu \mathrm{gg} / \mathrm{ml}) \quad \ldots \\
\text { Median iron saturation }(\%) \quad \ldots \\
\text { Proportion of patients drinking alcoh } \\
\text { Proportion of patients insulin depen }\end{array}$ & 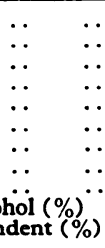 & $\begin{array}{l}\because \\
\because \\
\because \\
\because \\
\because \\
\because \\
\because \\
\because\end{array}$ & $\begin{array}{l}\cdots \\
\cdots \\
\cdots \\
\cdots \\
\therefore \\
\therefore \\
\therefore\end{array}$ & $\begin{array}{l}\cdots \\
\because \\
\because \\
\because \\
\because \\
\because \\
\because \\
\cdots\end{array}$ & $\begin{array}{c}46(20 \text { to } 59) \\
51 \\
99(72 \text { to } 140) \\
140(110 \text { to } 180) \\
88(70 \text { to } 110) \\
39 \\
3.9(1 \cdot 2 \text { to } 9 \cdot 3) \\
75(57 \text { to } 173) \\
29(17 \text { to } 53) \\
53 \\
76\end{array}$ & $\begin{array}{c}48(40 \text { to } 55) \\
75 \\
115(68 \text { to } 204) \\
175(120 \text { to } 220) \\
108(70 \text { to } 120) \\
33 \\
4 \cdot 4(1 \cdot 2 \text { to } 8 \cdot 0) \\
88(70 \text { to } 170) \\
28(24 \text { to } 49) \\
50 \\
50\end{array}$ & $\begin{array}{c}43(15 \text { to } 60) \\
56 \\
104(70 \text { to } 150) \\
150(120 \text { to } 180) \\
85(70 \text { to } 110) \\
60 \\
4 \cdot 2(1 \cdot 6 \text { to } 9 \cdot 0) \\
80(55 \text { to } 210) \\
24(20 \text { to } 63) \\
54 \\
54\end{array}$ & $\begin{array}{c}49(16 \text { to } 53) \\
38(a) \\
84(b)(70 \text { to } 130) \\
130(c)(110 \text { to } 170) \\
85(d)(70 \text { to } 110) \\
10 \\
3 \cdot 7(2 \cdot 7 \text { to } 12 \cdot 0) \\
90(48 \text { to } 158) \\
32(15 \text { to } 40) \\
41 \\
80\end{array}$ \\
\hline
\end{tabular}

a) $=\mathrm{P}<0.05$ ogainst High. $(b)=\mathrm{P}<0.02$ against High. $(c)=\mathrm{P}<0.01$ against High. $(d)=\mathrm{P}<0.05$ against High. 
the healthy contrast group and in the three groups of diabetic patients are shown in table I. The age, sex, weight, blood pressure, serum iron/saturation, faecal fat, the proportion of patients with ketonuria, and the proportion who drank alcohol in the three groups of diabetic patients are given in table II. Fasting serum insulin was significantly higher in the diabetic patients than in the contrast group and was significantly higher in the high/delayed secreting group than in the low secreting group. The increase in blood glucose 60 minutes after the oral glucose load was significantly greater in the low insulin secreting group than in the high or delayed group and there was a significant negative partial correlation between the rise in glucose and the rise in insulin concentration when the body weight was made constant $\left(r_{12.3}=0.45, P<0.01\right)$.

The increase in serum insulin after intravenous tolbutamide was significantly greater in the high/delayed insulin secreting group than in the low secreting group. A significantly greater proportion of men were in the low secreting group, and in this group there were more underweight patients, a greater proportion were insulin dependent, and their blood pressure was significantly lower. After intravenous tolbutamide only four of the 48 patients tested released more insulin than the lower 10th percentile of the contrast group $(+46 \mu \mathrm{U} / \mathrm{ml})$.

The fasting serum growth hormone concentration and the changes that occurred during the glucose tolerance test and after exercise are given in table III. The fasting serum growth hormone was significantly higher in the diabetic patients, there was significantly less depression during the glucose tolerance test, and a significantly greater rise after exercise. A rise in serum growth hormone during the glucose tolerance test occurred in half the diabetic patients but there was either no change or a fall in concentration in all subjects of the contrast group. There were significant negative correlations between the fasting serum growth hormone concentration and age $(r=0.47, P<0.005)$, weight $(r=-0.37, P<0.05)$, and blood pressure $(\mathrm{r}=-0.43, \mathrm{P}<0.01)$, and a significantly higher fasting concentration was found in patients with ketonuria $(2.5$ compared with $1 \mathrm{ng} / \mathrm{ml}, \mathrm{P}<0.01)$.

TABLE III-Fasting Serum Growth Hormone and the Changes During the Glucose Tolerance Test and After Exercise in the Diabetic Patients and in the Healthy Contrast Group. (Median Followed by 10th and 90th Percentiles)

\begin{tabular}{|c|c|c|}
\hline & Healthy Contrast Group & Diabetic Patients \\
\hline $\begin{array}{l}\text { Fasting }(\mathrm{ng} / \mathrm{ml}) \\
\text { Change at } 60 \mathrm{~min} \\
\text { Change at } 120 \mathrm{~min} \\
\text { Change after exercise }\end{array}$ & $\begin{aligned} 0.3(0 \text { to } 3.0) & (a) \\
-0.2(-8.0 \text { to } 0) & (b) \\
0(-1.0 \text { to } 0) & (c)\end{aligned}$ & $\begin{aligned} 1.0 & (0.8 \text { to } 5.0) \\
0 & (-2 \cdot 0 \text { to }+3.0) \\
0 & (-3.0 \text { to }+3.0) \\
+2.0 & (-0.2 \text { to }+3.0)\end{aligned}$ \\
\hline
\end{tabular}

$(a)=\mathrm{P}<0.05 . \quad(b)=\mathrm{P}<0.01 . \quad(c)=$ Range; $\mathrm{P}<0.02$.

Altogether, 23 diabetic patients, including three with pancreatic calcification, passed more than $6 \mathrm{~g}$ /day of faecal fat. Compared with the other diabetic patients they were lighter (90\% compared with $100 \%$ of desirable weight; $r=-0.33$, $\mathbf{P}<0.005)$ and their fasting blood glucose was lower $(2.04 \mathrm{~g} / \mathrm{l}$. compared with $2.80 ; \mathrm{r}=-0.25, \mathrm{P}<0.03$ ) but there was no significant association with abdominal pain, ketonuria, alcohol consumption, or insulin dependence, and no correlation with the serum insulin, lipid, or iron concentrations.

The fasting cholesterol and triglycerides were significantly higher in the diabetic patients than in the healthy contrast group of African cleaners (table I); it was also found that African students receiving a Western diet had intermediate lipid concentrations (cholesterol 1.68 and triglycerides 1.20 $\mathrm{g} / \mathrm{l}$.) There were no significant differences in the non-esterified fatty acid concentrations, but in the diabetic patients it was significantly correlated with body weight $(r=+0.30, \mathrm{P}<$ 0.02).

\section{Discussion}

Both diabetic and healthy Africans (Wapnick et al., 1972) secrete far less insulin than Europeans (see chart) and a high proportion $(76 \%)$ of the diabetic patients are insulin dependent. Siderosis (Seftel $\epsilon t$ al., 1960) is unlikely to be the cause of this insulinopenia since there was no correlation between insulin secretion and serum iron concentration/saturation. Diet is a more likely explanation. It contains a high proportion of unrefined carbohydrate (maize meal) which is slowly digested (van der Westhuysen et al., 1972) and slowly absorbed and is consequently a poor stimulus for the release of insulin and duodenal insulinotrophic hormones. Diabetic patients from rural areas ate a significantly higher proportion of refined carbohydrate (sugar and white bread) than non-diabetic patients (Wicks et al., 1972), suggesting that a change in diet can lead to glucose intolerance in susceptible patients (Cleave et al., 1969) and may account for the increase of diabetes in Rhodesia. Since 1962 there has been a two- to three-fold increase in the number of new diabetic patients admitted each year to Harare Hospital (Salisbury) and also to Mpilo Hospital (Bulawayo) (Z. Rachman, personal communication, 1972).

If Szanto and Yudkin (1969) )are correct, and an excess of insulin is essential for the development of coronary atherosclerosis, then the rarity of this disease in Rhodesia, and also in other developing countries, can be explained by the diet and the consequent low serum insulin concentration.

The very high proportion $(23 \%)$ of diabetic patients with steatorrhoea suggests that chronic pancreatitis may be an important factor in the aetiology of diabetes in Africans (Wicks and Clain, 1973) although, as Youngs (1972) has pointed out, a primary insulin deficiency can also lead to a secondary failure in exocrine pancreatic function.

When the diabetic patients are compared with a healthy group of urban Africans the proportion in each insulin secreting category (high/delayed, normal, or low) was very similar to a recent study on newly diagnosed patients in Glasgow (McKiddie et al., 1969). The high/delayed group showed many characteristics of typical adult European diabetes, including a significantly greater proportion of obese, female, hypertensive patients, with higher fasting insulin concentrations, less severe glucose intolerance, a greater release of insulin after tolbutamide, and a smaller proportion who were insulin dependent (see tables I and II).

In contrast to insulin the secretion of growth hormone closely resembled reports on European populations, showing a relatively high fasting concentration (Drash, 1968; Hansen, 1970; Lundbaeck et al., 1970), no fall during the glucose tolerance test (Yalow et al., 1965), and an excessive rise during exercise (Hansen, 1970; Lundbaeck et al., 1970) (table III); and the serum lipids showed the expected increase in diabetic patients compared with the healthy contrast group (table I).

We wish to thank Professor M. Gelfand, Dr. E. Taube, Dr. J. I. Forbes, and Mr. D. R. Barley for permission to study their patients and records, Mr. E. Kanengoni and Mr. M. T. Mbizvo for assaying the hormones, Miss C. Handke, Messrs K. G. Nott, G. Parish, F. Chimambo, S. Mujanja, T. Chimbadzwa, and W. S. Kunzekweguta for technical help, the Secretary for Health (Rhodesia) for access to patients in Harare Hospital, and the University of Rhodesia for a generous research grant.

This work forms part of A.C.B.W.'s M.D. thesis to be submitted to Birmingham University.

\section{References}

Bothwell, T. H., Jacobs, P., and Kamener, R. (1959). South African fournal of Medical Science, $24,93$. Bothwell, T. H., and Mallet, B. (1955). Biochemical fournal, 59, 599.
Cleave, T. L., Campbell, G. D., and Painter, N. S. (1969). Diabetes, Coronary Thrombosis and the Saccharine Disease, Bristol, Wright. Drash, A., et al. (1968). Pediatric Research, 2, 94. 
Duncombe, W. G. (1964). Clinica Chimica Acta, 9, 122.

Eggstein, M. (1966). Klinisch Wochenzeitschrift, 44, 267. Hales, C. N., and Randle, P. J. (1963). Lancet, 1, 200. Hånsen, A. P. (1970). Fournal of Clinical Investigation, 49, 1467. Jackson, W. P. U., Goldin, C., and Marine, N. (1966). South African Medical fournal, 40, 206.

Lundbaeck, K., et al. (1970). Lancet, 2, 131.

McKiddie, M.'T., Buchanan, K. D., and Hunter, I. A. (1969). Quarterly Fournal of Medicine, 38, 445 .

Schalch, D. S., and Parker, M. L. (1964). Nature, 203, 1141.

Seftel, H. C., Isaacson, C., and Bothwell, T. H. (1960). South African

fournal of Medical Science, 25, 89

Seftel, H. C., and Walker, A. R. P. (1966). Diabetologia, 2, 286.
Szanto, S., and Yudkin, J. (1969). Postgraduate Medical fournal, 45, 602. Tulloch, J. A. (1966). Diabetes Mellitus, ed. L. J. P. Duncan, p. 115. Edinburgh, University Press.

Wapnick, S., Wicks, A. C. B., Kanengoni, E., and Jones, J. J. (1972). Lancet, 2, 300.

Watson, D. (1960). Clinica Chimica Acta, 5, 637.

van der Westhuysen, J., Mbizvo, M. T., and Jones, J. J. (1972). Lancet, 2, 719.

Wicks, A. C. B., Castle, W., and Gelfand, M. (1972). Diabetes. In press.

Wicks, A. C. B., and Clain, D. C. (1973). In preparation.

Yalow, R. S., Glick, S. M., Roth, J., and Berson, S. A. (1965). Annals of the New York Academy of Sciences, 131, 357.

Youngs, G. (1972). Gut, 13, 154.

\title{
Chronic Bronchitis: Method of Cigarette Smoking
}

\author{
J. RIMINGTON
}

British Medical fournal, 1973 1, 776-778

\section{Summary}

Male volunteers for mass radiography examination, aged 40 or more, were questioned about their sputum production, smoking habits, and, when applicable, their method of smoking cigarettes.

Of 5,438 cigarette smokers $460(8.4 \%)$ smoked their cigarettes without removing the cigarette from the mouth between puffs ("drooping" cigarette smokers) whereas the rest smoked in the normal manner.

Persons who admitted to producing sputum from their chests on most days of the year or on most days for at least three months of the year for a minimum of two years were classified as chronic bronchitics in the absence of other causative disease.

The rate of chronic bronchitis among the "drooping" cigarette smokers $(41.5 \%)$ was considerably greater than that among those smoking cigarettes in the normal manner $(33.6 \%)$. The same pattern was maintained when age and cigarette consumption were standardized, though "drooping" cigarette smokers had a slight bias towards plain as distinct from filter cigarettes and towards a lower social class this was not sufficient to account for the excess of chronic bronchitis among those using this method of smoking.

\section{Introduction}

Brett and Benjamin (1968), in an investigation of mortality in relation to smoking habits of men employed in industry, pointed out that those cigarette smokers who made a habit of retaining the cigarette in the mouth between puffs ("drooping" cigarette smokers) had a higher rate of lung cancer than those who removed the cigarette from the mouth between puffs. The higher rate of lung cancer in the former group was maintained irrespective of the number of cigarettes smoked.

This paper describes an investigation into the rate of chronic bronchitis among "drooping" cigarette smokers and compares it with the rate among those smoking cigarettes in

St. Thomas' Hospital, Stockport SK3 8BL

J. RIMINGTON, M.D., Medical Director, Regional Mobile Chest X-ray Service, Southern Division, Manchester Regional Hospital Board the normal manner. The definition of chronic bronchitis for the purposes of this study is the production of phlegm from the chest during the last two years, either on most days of the year or on most days during at least three months of the year.

\section{Subjects and Methods}

The data were obtained during 1970 and 1971 by questioning men from industry or from the general public who volunteered for mass radiography and who were aged at least 40 .

A smoking history was taken which included the amount, type, duration, and method of cigarette smoking and, in particular, each cigarette smoker was asked if he made a habit of keeping his cigarette in his mouth for most of the time or whether he removed it between puffs. A cigarette smoker was defined as one who had smoked at least one cigarette a day for as long as a year (Doll and Hill, 1950), and those who had stopped smoking at least two weeks before attending for mass radiography were classed as ex-smokers. Hand-rolled cigarette smokers were counted as cigarette smokers, the amount of tobacco used being converted to cigarette equivalents ( $1 \mathrm{oz}$. $(28 \mathrm{~g})$ a week = four cigarettes a day). Mixed smokers-that is, those smoking at least one cigar a week or 1 oz. $(28 \mathrm{~g})$ of pipe tobacco a month in addition to their cigarettes-were excluded from the study.

Each volunteer was asked if he brought up or coughed up phlegm from his chest and, if so, whether this was on most days of the year or on most days for at least three months of the year, and for how many years he had done this. All volunteers with incomplete or invalid records $(2.4 \%)$ were excluded, as were 68 persons whose subsequent chest $x$-ray films showed disease or abnormality (other than changes sometimes seen in chronic bronchitics) which was thought likely to be the cause of their persistent sputum-for example, certain tuberculous disease, lung cancer, bronchiectasis, etc.

Most of the volunteers in this study lived or worked in towns within the South-east Lancashire conurbation.

\section{SMOKING HABITS}

The smoking habits of the volunteers are compared in table I with a nationwide sample taken in 1968 (Todd, 1969). The figures given for the nationwide sample are recalculations of the original figures after the exclusion of the mixed smokers. It will be seen that the smoking habits of the volunteers are almost identical with those of the nationwide sample. 